\title{
Aquatic Activities As Play Therapy Children Autism Spectrum Disorder
}

\author{
Diajeng Tyas Pinru Phytanza ${ }^{1}$ (D) and Erick Burhaein ${ }^{2 *}$ (D) \\ ${ }^{1}$ Special Education, Faculty of Education, Universitas Negeri Yogyakarta, Indonesia \\ ${ }^{2}$ Sports Education, Doctoral Program of School of Postgraduates Studies, Universitas Pendidikan Indonesia, Indonesia \\ *Corresponding author: erick.burhaein@upi.edu
}

\begin{abstract}
This paper examines science theoretically with the method of literature aimed at writing this article to explore the optimization of aquatic activity as a play therapy for children with autism spectrum disorder (ASD). ASD children have major problems in communication, social interaction, behavior, interests, and motor skills. These disorders are important to overcome with the right treatment. Play therapy is one method that can be used to improve psychological and physical aspects. Aquatic activities as a form of play therapy are in the program sed adi five games aquatic include: 1) Fishing Nets Games; 2) Game Touching a Ball or Object; 3) Mini Water Polo Game; 4) Game Looking For Objects/ Coins; 5) Game of Sowing Objects/ Coins. The aquatic game in the program can improve and develop aspects of psychology, namely behavior, emotions, and social, with communication included. Aquatic activity as a program cannot be separated from the concept of frequency, intensity, time, and type (FITT), psychic therapy program as well as an exercise program to improve the aerobic, flexibility, and neuromuscular components in ASD children and adolescents. Based on the results of previous studies found that the aquatic activity has a significant effect as a play therapy for ASD children. The conclusion of this article is that the aquatic game program can be used as a play therapy for ASD children. The program was given by paying attention to the FITT concept during the five aquatic game program.
\end{abstract}

\section{Keywords}

Aquatic Activity, Autism Spectrum Disorder, Play Therapy

\section{INTRODUCTION}

Exhom (2005), autisme a term formerly pften used by most people when referring to the spectrum of autistic disorders. The more relevant term used today for autism is autism spectrum disorder or autism spectrum disorder). Merianto (2016) children with autism spectrum disorder (ASD) in general have disorders in terms of communication, social interaction and behavior so it is important to get special treatment that is different from children in general.

Barriers or problems of social interaction and behavior in ASD students are handled by paying special attention to children (Ulfah, 2015). Special forms of attention are carried out by providing appropriate treatment and in accordance with the child's condition. The form of giving assistance to ASD children in accordance with the needs aims to make the socialization of children with the environment run well and increasingly have independence.

Ulfah (2015) certain activities that support social interaction and behavior are able to develop the abilities of ASD children in terms of cognitive, psychomotor, and affective aspects. These activities can be done in the form of therapy. Merianto (2016) therapy is a supporter of the development of both cognitive and behavioral aspects in children with autism, because the progress experienced by children with autism will further facilitate assistance by parents/ teachers. Therapy programs, there are several types including physio therapy, acupuncture therapy, play therapy, music therapy, orthopedic surgery. Play therapy is expected to be able to 
improve interaction, communication, and the ability to play integratively (Sumaryanti, 2005).

Based on the background explanation above, the authors would like to uncover/ theoretically study the optimization of aquatic activity as a play therapy for children with autism spectrum disorder (ASD).

\section{DISCUSSION}

\section{A. Characteristics of Children with Autism Spectrum Disorder}

ASD children are developmental disorders that affect the way a person communicates, reacts, and behaves in life (Suteja, 2014). Autism behavior is usually characterized by low verbal and non verbal communication, social interactions that seem strange, emotions that are not stable, changeable and sensory perceptions that are not optimal (Phandinata, Atmodiwirjo, \& Basaria, 2017).

Children with ASD, which causes the genetic factors tend to be more difficult to be able to improve its development disorder, a boy with autism who causes through social formations tend to be easier to be directed so that parents / teachers 1 ore is also to optimize the improvement of disorders of development (Suteja, 2014).

The characteristics of ASD children based on Diagnostic and Statistical Manual of Mental Disorders (DSM) version five or DSM-V, as follows (American Psychiatric Association, 2013).

1. Continual deficits in social communication and social interaction in various contexts.

a. Deficits in social-emotional reciprocity, starting, for example, from abnormal social approaches and failure of normal back and forth conversation; to reduce the sharing of interests, emotions, or influence; failure to start or respond to social interactions.

b. Deficits in nonverbal communicative behavior that are used for social interaction, starting, for example, from verbal and nonverbal communication that are less integrated; abnormalities in eye contact and body language or deficits in understanding and using cues: total lack of facial expression and nonverbal communication.

c. Deficits in developing, maintaining, and understanding relationships, start, for example, from the difficulty of adjusting behavior to fit various social contexts; difficulty in imaginative games or in making friends; no interest in peers.

2. Recurring behavior patterns and restricted interests or activities.

a. Stereotypic or repetitive motor movements, use of objects, or speech (for example, simple motor stereotypes, queued toys or flipping objects, echolalia, idiosyncratic phrases).

b. Inflexible adherence to routine or ritual patterns of verbal or nonverbal behavior (eg, extreme pressure on small changes, difficulty with transitions, rigid thinking patterns, the ritual greeting, need to take the same route or eat the same food every day).

c. Very limited, abnormal focused interest in intensity or focus (for example, strong attachment or preoccupation with unusual objects, overly constrained or persuasive interests).

d. Hyper or hypo reactivity to sensory input or unusual interest in sensory aspects of the environment (for example, clear disregard for pain / temperature, adverse responses to certain sounds or textures, excessive odor or touching an object, visual appeal with light or movement).

3. Symptoms must be present in the early development period (but may not be fully realized until social demands exceed limited capacity, or may be masked by strategies learned later on).

4. Symptoms cause clinically significant disorders in the social, occupational or other important areas of current functioning.

5. This disorder is not better explained by intellectual disability (impaired intellectual development) or delays in global development. Intellectual deficiency and autism spectrum disorders often occur together; to make a diagnosis of comorbid autism spectrum disorders and intellectual disabilities, social communication must be below the expected level of general development.

\section{B. Play Therapy}

Sumaryanti (2005) play therapy can be used for various purposes, both to improve physical, mental, and social quality. Play therapy is one method of therapy, of course this therapy must be adjusted to the characteristics of children who 
really need to get therapy. The characteristics of children who need to get therapy include : (1) autism, (2) hyperactivity, (3) phobia (victims of natural disasters ,

abductions, etc.). Autism, which is now merged in terms of autism spectrum disorder (ASD) is one of the characteristics that needs to be treated. An autistic child has a habit of being physically, mentally, and behaviorally disturbed so that the child is often isolated from the environment due to his own unwilling attitudes not being regulated and behavior is not directed (Suteja, 2014).

The essence of giving therapy is reconditioning the child to a better condition than before, there is a slight positive change. Suteja (2014) play therapy intended that autistic children have always had a cheerful and happy attitude, especially with peers. This is very useful to help children with autism be able to socialize with other children.

Play therapy is capable of provide a positive stimulus for the child, because playing is the activity of natural for children to get to know his world, expresses the thought of her and her feelings, develop social skills and learning for himself (Phytanza, Burhaein, Sukoco, \& Ghautama, 2018). Play therapy as a medium for children to explore the relationship with his friend and expressed his hopes and experience through playing.

\section{Aquatic Activity}

Aleksandrovic, Jorgic, Block, \& Jovanovic (2015) Aquatic activities are physical activities carried out in water, where adaptive physical activities are adapted to certain conditions such as disability. Aquatic activities have many benefits for disability (Stan, 2012), as follows.

\section{Physical Benefits}

The physiological benefits of aquatic activity are divided into two: the biological effects of water and the physical and therapeutic benefits of participation in aquatic activities.

\section{a. Effects Biologic of Water}

Benefits biological immersing the body in water up to the chest (or higher), including lymphatic compression, compression of the vein, the increase in central blood volume, increased volume of the heart, increased atrial pressure, increased stroke volume, increased cardiac output, increased work of breathing, increased oxygen delivery, increased dependent edema, increased muscle blood flow, weight unloading, decreased joint compression with movement, increased flow to the kidneys, higher pain threshold, suppressed sympathetic nervous system activity, and promotion of excretion of metabolic waste.

\section{b. Benefit of Physical and Therapeutic}

Movement water through aquatic activities that are tailored to the program can generate the following physical benefits: relaxation, relieve pain and muscle spasm, maintain or increase range of motion in joints, muscle reeducation paralyzed, and increased strength and muscle endurance. To achieve the goals (benefits) for children with disabilities, physical, and occupational therapists can help accompanying teachers, class teachers, and physical education teachers to provide aquatic activities that are beneficial as both therapeutic and educational for children.

\section{Social and Emotional Benefits}

The quality Aquatic Activity Program can facilitate social and emotional benefits besides physical health. Activities aquatic made with a fun program to give children experience in the group, providing a sense of freedom (of self-exploration), as well as self-relaxation of tension. The excitement when doing aquatic activities is a "social asset" that can provide stimulants to selfimage, which is a strong motivation to be more interested in further or other activities. The confidence of a child raised under the influence of a sense of fun to play with friends, in which the condition affects the nervous system pusaf se to stimulate the secretion of hormones certain that bring a sense of fun. Burhaein (2017) explains that certain hormones that can improve mood (psychological mood) include norepinephrine, serotonin, and dopamine.

\section{Cognitive and Intellectual Benefits}

Several facilitators of aquatic activity have integrated academic learning with aquatic adaptation that will influence the success of strengthening cognitive concepts. Children can count certain objects from plastic or which are not easily wet on the surface of the water, or dive to pick up objects, or they can describe the basic conditions of the water after diving into objects taken at the bottom of a pond. 


\section{Benefits of Recreation}

Most recreational arrangements (separate, integrated and inclusive) must be available to match individual capacity and the objectives of the aquatic program to be achieved. In general recreational activities, the majority believes that all individuals must participate together.

Activities of individual (separate) can indeed prevent insubordination communication ASD child in the group due to lack of communication, but the activity of the form teams provide an experience for children to develop themselves by carrying an group it will tend to be an impact on social behavior and communication skills (Sowa \& Meulenbroek, 2012). The following is a game in Aquatic Activities in the form of groups between groups and individuals that are in the competition of one group.

Table 1. Examples Games in Aquatic Activity

\begin{tabular}{|c|c|c|c|c|}
\hline No & Aquatic Activity & Type & Description & Development Aspects \\
\hline 1 & Fishing nets games & $\begin{array}{l}\text { Individual } \\
\text { to Group } \\
\text { Games }\end{array}$ & $\begin{array}{l}\text { The game starts } \\
\text { with 2-3 children as } \\
\text { a net, then catches } \\
\text { fish and then } \\
\text { changes as a net and } \\
\text { so on. }\end{array}$ & $\begin{array}{l}\text { Behavior : courage ; } \\
\text { Emotional:self-exploration; } \\
\text { Social:cooperation, } \\
\text { communication }\end{array}$ \\
\hline 2 & $\begin{array}{l}\text { game touching a } \\
\text { ball or object }\end{array}$ & $\begin{array}{l}\text { Group } \\
\text { Games / } \\
\text { Individual } \\
\text { Games }\end{array}$ & $\begin{array}{l}\text { It is recommended } \\
\text { to do in groups, } \\
\text { each } \\
\text { player competes to } \\
\text { touch objects } \\
\text { according to } \\
\text { instructions and the } \\
\text { specified distance. }\end{array}$ & $\begin{array}{l}\text { Behavior: honest, sportive } \\
\text { Emotional: self-exploration } \\
\text { Social: cooperation, } \\
\text { communication }\end{array}$ \\
\hline 3 & $\begin{array}{l}\text { Mini Water Polo } \\
\text { game }\end{array}$ & $\begin{array}{l}\text { Group } \\
\text { Games }\end{array}$ & $\begin{array}{l}\text { Water polo can be } \\
\text { done between teams } \\
\text { of } 3-4 \text { children each, } \\
\text { done alternately as } \\
\text { an attacking and } \\
\text { defending team. }\end{array}$ & $\begin{array}{l}\text { Behavior: honest, sportive } \\
\text { Emotional: self-exploration } \\
\text { Social: cooperation, } \\
\text { communication }\end{array}$ \\
\hline 4 & $\begin{array}{l}\text { Game Looking For } \\
\text { Objects/ Coins }\end{array}$ & $\begin{array}{l}\text { Group } \\
\text { Games }\end{array}$ & $\begin{array}{l}\text { Conducted in } \\
\text { groups, each group } \\
\text { was given the same } \\
\text { task, the winning } \\
\text { team is first pick up } \\
\text { objects. }\end{array}$ & $\begin{array}{l}\text { Behavior: honest, sportive } \\
\text { Emotions: self-exploration } \\
\text { Social: cooperation, } \\
\text { communication }\end{array}$ \\
\hline 5 & $\begin{array}{l}\text { Game of Sowing } \\
\text { Objects/ Coins }\end{array}$ & $\begin{array}{l}\text { Group } \\
\text { Games / } \\
\text { Individual } \\
\text { Games }\end{array}$ & $\begin{array}{l}\text { The game can be } \\
\text { done in the form of } \\
\text { teams, working } \\
\text { together to find } \\
\text { objects dropped into } \\
\text { the pool. }\end{array}$ & $\begin{array}{l}\text { Behavior: honest, sportive } \\
\text { Emotional: self-exploration: } \\
\text { Social cooperation, } \\
\text { communication }\end{array}$ \\
\hline
\end{tabular}

Source: Author

ASD children who participate

in aquatic activities need to pay attention to the element of security, so that goals or benefits can be achieved. There are precautions that can be taken and considered to maintain safety (Grosse, 2014) 


\section{Precautions in Aquatic Programs}

a. Continuous supervision of children during the program. Unused equipment is kept out of the reach of children, and close to the reach of program companions.

b. Ask about the child's condition before, during and after the program. Make sure the child is in good health during the program.

c. Provide an explanation of the procedures and rules in the pool to every child and me have each child carry out and obey.

d. Strengthening the rules and procedures every time ASD behavior appears while in the pool.

e. Provide aquatic experience designed to help individuals with ASD to learn water safety knowledge and skills. It starts with learning not to approach water without permission, staying in one assigned area, and following instructions and then proceeding to the level of swimming skills.

f. Children with ASD characteristics tend to learn skills following an example provided by a companion.

g. Avoid rules that change, because it will affect when children respond in the form of disappointment.

h. Beware of children who are running or doing activities by away from the main pool (aquatic activity activities). Pay

attention to the swimwear used, adjust it to safety standards.

i. Prepare a quiet place for ASD children so that emotional control during stress can be maintained.

2. Preventive Measures

with

\section{Family, Friends and}

\section{or Companions Aquatic activities}

a. Someone who has ASD must always swim and / or participate in aquatic activities in the supervision of the pool life guard and other responsible parties physical education teacher as the main assistant of the program is assisted by class teachers and parents .

b. Supervision of ASD is carried out continuously and at any time by a companion, friends (who have a fairly good independence) and parents.

c. Provides clear boundaries

of aquatic activity areas, can use floating balls arranged in a line. Visual limits provide effectiveness and efficiency in supervision.

d. Make an interesting concept of aquatic activities, to reduce the eye contact of ASD children outside the activity area. Children who go outside the area or not according to instructions, are at risk of training accidents such as injury, drowning, or other risks. Companion, family, and friends are always wary of ASD children.

\section{OPTIMIZATION OF AQUATIC} ACTIVITIES AS THERAPYING CHILDREN AUTISM SPECTRUM DISORDER

\section{Children with Autism Spectrum Disorder} (ASD), there are two main aspects of characteristics according to DSM-V, namely social communication and limited interests or activities and repetitive behavior. Both characteristics are divided into three levels, namely: 1) level 1 requires support/ requiring support);2) level 2 requires substantial support / substantial requiring support);3) and level 3 requires very large support or substantial/ substantial requiring very substantial support (American Psychiatric Association, 2013).

The authors compile this program aimed at ASD-level 1 because the disturbance experienced is lighter than level 2 and 3 , so there is an assumption to be more likely to be optimized. DSM-V explains the characteristics of DSM-level 1 seen from social communication and limited interests or activities and repetitive behavior (American Psychiatric Association, 2013), as follows.

\section{Social Communication}

Without support in place, deficits in social communication cause real disruption. Difficulty starting social interactions, and clear examples of non-typical or unsuccessful responses to other people's social offers. It might appear to have decreased interest in social interaction. For example, a person who is able to speak in complete sentences and is involved in communication but who is trying to get friends and usually tends to be less successful.

\section{Limited Interest or Activity and Repetitive Behavior}

The inflexible nature of behavior causes significant disruption in one or more 
contexts. Difficulty switching between activities. Problems of organizing and selfindependence.

Aquatic activity as a play therapy that has been programmed must of course meet the standard training programs that contain elements of FITT. Aquatic games not only provide psychological benefits, but also provide benefits to the biomotor components of children who are trained during the program. Here's a physical activity program for children and adolescents with autism spectrum disorder (Srinivasan, Pescatello, \& Bhat, 2014).

Table 2. Physical Activity Program for Children and Adolescents with ASD

\begin{tabular}{lll}
\hline $\begin{array}{c}\text { Exercise } \\
\text { Component }\end{array}$ & \multicolumn{1}{c}{ Initial Program } & \multicolumn{1}{l}{ Advanced courses } \\
\hline Program of aerobic exercise for children and adolescents ASD \\
\hline Frequency & 3 days / week & 5 days/week, every day of the week \\
\hline Intensity & Moderate / moderate physical activity & Strong / high physical activity \\
\hline Time & 20-30 minutes / day accumulates & $\begin{array}{l}\text { 45-60 minutes/day } \\
\text { with games short }\end{array}$ \\
& Swimming, aquatic activity & Swimming, aquatic activity \\
\hline Type & \multicolumn{2}{c}{ Activities Physical moderate / moderate } \\
\hline Flexibility and neuromuscular exercise programs for ASD children and adolescents \\
\hline Frequency & 60 minutes (1 hour) \\
\hline Intensity & Muscle stretching exercises for the main arm and leg muscles, aquatic activity \\
\hline Time &
\end{tabular}

Aquatic activities provide optimal influence on the physical and psychological through play therapy, reinforced by research related to aquatic activity and play therapy for children with ASD as follows.

Table 3 . Research Related to Aquatic Activity and Play Therapy for ASD Children

\begin{tabular}{|c|c|c|c|}
\hline No & Reference & Research Methods & Findings \\
\hline 1. & Suryati (2016) & Experiment & $\begin{array}{l}\text { there is a significant influence of play therapy on } \\
\text { the social interactions of children with autism. }\end{array}$ \\
\hline 2. & $\begin{array}{l}\text { (Tambunan \& } \\
\text { Matulessy, } \\
\text { 2015) }\end{array}$ & Experiment & $\begin{array}{l}\text { play therapy has a significant effect on autistic } \\
\text { children to improve eye contact ability, and } \\
\text { receptive language skills but has less influence on } \\
\text { imitation (imitating) and expressive language skills. }\end{array}$ \\
\hline 3. & $\begin{array}{l}\text { (Aleksandrovi } \\
\text { et al., 2015) }\end{array}$ & $\begin{array}{l}\text { Systematic Review : } \\
13 \text { research }\end{array}$ & $\begin{array}{l}\text { aquatic programs for at least } 10 \text { weeks can affect } \\
\text { the improvement of aquatic skills in children } \\
\text { with ASD, through the use of learning methods that } \\
\text { are used well with the help of siblings or peers. }\end{array}$ \\
\hline 4. & $\begin{array}{l}\text { Mortimer, } \\
\text { Privopoulos, \& } \\
\text { Kumar (2014) }\end{array}$ & Systematic Review & $\begin{array}{l}\text { data showing that individuals with ASD who } \\
\text { participate in an aquatic therapy program increase } \\
\text { physical activity and improve cardiorespiratory } \\
\text { function, muscle strength and endurance. }\end{array}$ \\
\hline 5. & $\begin{array}{l}\text { Caputo et al. } \\
\text { (2018) }\end{array}$ & Experiment & $\begin{array}{l}\text { Therapeutic aquatic multisystem effective to } \\
\text { improve functional impairment in children with } \\
\text { ASD after following aquatic programs. }\end{array}$ \\
\hline 6. & $\begin{array}{l}\text { Kanupka et al. } \\
\text { (2018) }\end{array}$ & Experiment & $\begin{array}{l}\text { The results show that aquatic programs can lead to } \\
\text { better behavior and are socially valid interventions } \\
\text { considered as safe and effective behavioral } \\
\text { interventions in children with ASD. }\end{array}$ \\
\hline
\end{tabular}


Based on the studies that have been presented above, it can be concluded that there is a significant effect of play therapy on social interactions increasing the ability of eye contact, and receptive language skills of children with autism. Subsequent reductions were found that that aquatic activity as a therapy can increase physical activity, improve cardiorespiratory function, muscle strength and endurance, improve functional disorders, and better, safe and effective behavior for ASD.

\section{CONCLUSION}

The conclusion of this article is that the aquatic games program can be used as play therapy for ASD children. The program is given by paying attention to the concept of FITT (frequency, intensity, time, type) during the five-aquatic game program as play therapy . Based on the results of previous studies found that the aquatic activity has a significant effect as a play therapy for ASD children. The author suggests further studies related to testing the effectiveness and influence of this aquatic activity program as play therapy for ASD children through field research.

\section{REFERENCES}

Aleksandrovic, M., Jorgic, B., Block, M., \& Jovanovic, L. (2015). the Effects of Aquatic Activities on Physical Fitness and Aquatic Skills in Children With Autism Spectrum Disorders: a Systematic Review. Life Skills Journal of Psychology, 13(3), 351-362.

American Psychiatric Association. (2013). Diagnostic and Statistical Manual of Mental Disorders (DSM-5). American Psychiatric Pub.

Burhaein, E. (2017). Aktivitas Permainan Tradisional Berbasis Neurosainslearning Sebagai Pendidikan Karakter Bagi Anak Tunalaras. Jurnal SPORTIF: Jurnal Penelitian Pembelajaran, 3(1), 55. https://doi.org/10.29407/js_unpgri.v3i1.580

Caputo, G., Ippolito, G., Mazzotta, M., Sentenza, L., Muzio, M. R., Salzano, S., \& Conson, M. (2018). Effectiveness of a Multisystem Aquatic Therapy for Children with Autism Spectrum Disorders. Journal of Autism and Developmental Disorders, 48(6), 1945-1956. https://doi.org/10.1007/s10803-017-3456-y
Exhorn, K. S. (2005). The Autism Sourcebook. Everything You Need to Know About Diagnosis, Treatment, Coping, and Healing. 107-108.

Grosse, S. J. (2014). Aquatic Safety for Individuals with Autism Spectrum Disorders. International Journal of Aquatic Research and Education, 8(3). https://doi.org/10.25035/ijare.08.03.08

Kanupka, J. W., Oriel, K. N., George, C. L., Crist, L., Deardorff, K., Douglass, D., ... Wirick, D. (2018). The impact of aquatic exercise on sleep behaviors in children with Autism Spectrum Disorder. Journal of Intellectual Disability - Diagnosis and Treatment, 6(1), 1-7. $\quad$ https://doi.org/10.6000/22922598.2018.06.01.1

Merianto, R. W. (2016). Peran orang tua dalam menangani anak autis. Jom Fisip, 3(1), 1-15.

Mortimer, R., Privopoulos, M., \& Kumar, S. (2014). The effectiveness of hydrotherapy in the treatment of social and behavioral aspects of children with autism spectrum disorders: A systematic review. Journal of Multidisciplinary Healthcare, 7(September), 93-103.

https://doi.org/10.2147/JMDH.S55345

Phandinata, S. R., Atmodiwirjo, E. T., \& Basaria, D. (2017). Developmental IndividualDifferences Relationship-Based (Dir) Floortime Dalam Meningkatkan Komunikasi Dua Arah Pada Kasus Autism Spectrum Disorder (Asd). Psibernetika, 10(2). https://doi.org/10.30813/psibernetika.v10i2.1 046

Phytanza, D. T. P., Burhaein, E., Sukoco, S., \& Ghautama, S. W. (2018). Life Skill Dimension based on Unified Sports Soccer Program in Physical Education of Intellectual Disability. Yaşam Becerileri Psikoloji Dergisi, 2(4), 199-205. https://doi.org/https://doi.org/10.31461/ybpd. 453865

Sowa, M., \& Meulenbroek, R. (2012). Effects of physical exercise on Autism Spectrum Disorders: A meta-analysis. Research in Autism Spectrum Disorders, 6(1), 46-57. https://doi.org/10.1016/j.rasd.2011.09.001 
Srinivasan, S. M., Pescatello, L. S., \& Bhat, A. N. (2014). Current Perspectives on Physical Activity and Exercise Recommendations for Children and Adolescents With Autism Spectrum Disorders. Physical Therapy, 94(6), 875-889.

https://doi.org/10.2522/ptj.20130157

Stan, A. E. (2012). The benefits of participation in aquatic activities for people with disabilities. Sports Medicine Journal / Medicina Sportiväф, 8(1), 1737-1742. Retrieved from http://search.ebscohost.com/login.aspx?direct $=$ true $\& \mathrm{db}=$ sph $\& A N=74249978 \&$ site $=$ ehost live

Sumaryanti, S. (2005). Aktivitas Terapi. Jakarta: Direktorat Pembinaan Sekolah Luar Biasa.

Suryati, R. (2016). Pengaruh terapi bermain terhadap interaksi sosial anak autis di SDLB Prof. Dr. Sri Soedewi Masjchun Sofwan, SH Jambi tahun 2014. Jurnal Ilmiah Universitas Batanghari Jambi, 16(1), 142-147.

Suteja, J. (2014). Bentuk dan Metode Terapi Terhadap Anak Autisme Akibat Bentukan Perilaku Sosial. Edueksos : Jurnal Pendidikan Sosial \& Ekonomi, 3(1), 119-133. https://doi.org/10.1002/hast.449

Tambunan, D. R., \& Matulessy, A. (2015). Pengaruh Terapi Bermain FlashcardUntuk Meningkatkan Interaksi Sosial Pada Anak Autis di Miracle Centre Surabaya. Persona:Jurnal Psikologi Indonesia, 4(1), 51-60.

https://doi.org/10.30996/persona.v4i1.490

Ulfah, I. M. (2015). Interaksi Sosial Peserta Didik Autis di Sekolah Inklusif. Jurnal Pendidikan Khusus, 5(1), 1-8. 